\title{
BIOCHEMICAL MECHANISMS OF RESISTANCE TO $p$-NITROCHLOROBENZENE OF KARST CAVES MICROORGANISMS
}

\author{
O. S. SUSLOVA', P. V. ROKITKO ${ }^{1}$, K. M. BONDAR, \\ O. O. GOLUBENKO', A. B. TASHYREV ${ }^{1}$ \\ ${ }^{1}$ Zabolotny Institute of Microbiology and Virology, \\ National Academy of Sciences of Ukraine, Kyiv; \\ ${ }^{2}$ Taras Shevchenko National University of Kyiv, Ukraine; \\ e-mail: olga.suslova11@gmail.com
}

The biochemical mechanisms of resistance to persistent organic xenobiotic p-nitrochlorobenzene (NCB) of bacterial strains isolated from two cave clays ecosystems - Mushkarova Yama (Podolia, Ukraine) and Kuybyshevskaya (Western Caucasus, Abkhazia) have been established. It has been determined that chemoorganotrophic karst caves strains could interact with NCB and transform it reducing the nitro group with formation of p-chloroaniline (ClA) followed by further destruction of NCB aromatic ring. This explained high resistance of caves strains to NCB. The studied strains could potentially be used in wastewater treatment from nitrochloraromatic compounds.

Key word s: biochemical mechanism, microbial biodestruction, p-nitrochlorobenzene, organic xenobiotics.

$\mathrm{O}$ ne of the main sources of pollution is wastewater from organic synthesis. Xenobiotics which included both nitro group, chlorine and aromatic ring are of special danger to the biosphere. Among such compounds is p-nitrochlorobenzene (NCB). Its toxicity is determined by the aromatic ring and attached chlorine and nitro group in the para-position. Bactericidal concentration of NCB for most soil and aquatic chemoorganotrophic microorganisms is $10 \mathrm{mg} / \mathrm{l}$ [1]. However, in several papers [2-4] the viability of microbial communities was demonstrated in the presence of well-known bactericidal concentrations of extreme factors, but even at very high.

The aim of this work was to determine biochemical mechanisms of NCB destruction by bacterial strains isolated from Mushkarova Yama and Kuybyshevskaya cave clays which could explain the bacterial viability in the NCB concentration gradient.

\section{Materials and Methods}

The objects of study were chemoorganotrophic aerobic microbial communities and dominant ${ }^{1}$ strains isolated from the cave clays. One clay sample was collected in the farthest point from the entrance of the Mushkarova Yama labyrinth cave laid in the Neogenic gypsum in Podolia, Ukraine. Another sample was collected in the bottom hall of Kuybyshevskaya vertical cave formed in the Jurassic limestones of the Western Caucasus, at the $1 \mathrm{~km}$ depth. After collecting both samples were stored in a refrigerator at $4{ }^{\circ} \mathrm{C}$ in sealed plastic bags. Microorganisms isolated on agar media: nutrient agar (HiMedia Laboratories Pvt. Ltd.) and oligotrophic agar (OA). Concentration of organic compounds in the medium is determined by permanganate redox titration method [5]. For oligotrophic medium (OA) nutrient broth (HiMedia Laboratories Pvt. Ltd.) was diluted 10 times with distilled water and agarized (15 g/l). Colonies morph types obtained on the agar medium from maximum ten-fold dilutions of clays were reisolated three times to check the purity of the culture and in order to get single colonies. Thus 25 dominant strains were isolated from the studied cave clays.

Strains resistance to NCB were determined in a liquid medium (NB, oligotrophic broth) in a concentration gradient of the xenobiotic (50-300 mg/l). Controlled parameter was the biomass growth determined photocolorimetrically by optical density

${ }^{1}$ Dominant strains in the microbial community means isolated from maximum ten-fold dilutions of caves clays samples. 
of the liquid culture on KFK-2MP (ZOMZ, Russia) $(\lambda=540 \mathrm{~nm})$. Inoculated medium without xenobiotic was used as a growth control.

Determination of the strains ability to transform xenobiotic. Microorganisms are cultured in NCB concentration gradient (50-300 mg/l) in NB medium during three days. Concentration of NCB and chloroaniline (ClA) was determined by mass spectrometry using gas chromatography-mass-spectrum system Agilent 6890N/5973inert (capillary column HP-5MS (J\&W Scientific, USA)). Gas carrier - helium; initial column temperature $-150{ }^{\circ} \mathrm{C}$; final column temperature $-250^{\circ} \mathrm{C}$; temperature gradient $-4{ }^{\circ} \mathrm{C} / \mathrm{min}$; interface temperature $-280^{\circ} \mathrm{C}$; type ionization - electron impact; ionization energy $-70 \mathrm{eV}$. For this, the culture liquid was centrifuged (1700 g, $15 \mathrm{~min})$. Hexane $(0.5 \mathrm{ml})$ was added to the supernatant $(0.7 \mathrm{ml})$ and suspended for $3 \mathrm{~min}$. Next, the suspension was centrifuged (360 g, $10 \mathrm{~min}$ ) to separate phases. Thereafter, hexane was collected $(0.4 \mathrm{ml})$ and analyzed. Data processing of gas chromatography-mass spectrometry analysis was performed using the computer program ChemStation and integrated database of mass spectra NIST 02.

All experiments were run thrice. Experimental data were analyzed by statistical methods in Excel, $P \leq 0.05$.

\section{Results and Discussion}

Mushkarova Yama and Kuybyshevskaya cave clay samples were collected in zones free of anthropogenic load, which provided no influence of an- thropogenic factors on microbial communities. We isolated 25 bacterial strains from cave clay samples. The majority was highly resistant to NCB. Such high resistance could be explained by the fact that they were able to transform xenobiotic. There three most probable ways of nitroclorinearomatic compounds transformation: nitro group reduction, dehalogenation and aromatic ring reduction [6-8].

Previously it was shown the non-specific $p$-nitrochlorobenzene reduction on the example of facultative and obligate anaerobic bacteria museum cultures [9]. Microorganisms can degrade xenobiotic in two ways: reduction to $p$-chloroaniline ( $p$-ClA); reduction of the aromatic ring with subsequent cleavage of the cyclic compound. We have shown that consistent transformation of NCB by these two ways was possible as well (Fig. 1). At the first stage NCB transformed to ClA. At the second stage the concentration of $\mathrm{ClA}$ was reduced and apparently aromatic ring was destroyed.

A consistent transformation of NCB could be observed on the example of two strains P3 and P11 isolated from Mushkarova Yama karst cave clay. Strain P3 transformed NCB to ClA almost completely and halved its concentration. Strain P11 also reduced NCB concentration in comparing with its initial concentration $(50 \mathrm{mg} / \mathrm{l})$ and destroyed the $\mathrm{ClA}$ almost completely.

The absence of stoichiometric ratio between the initial and final concentrations of NCB and ClA indicated deep xenobiotic degradation, apparently due to the destruction of aromatic ring.

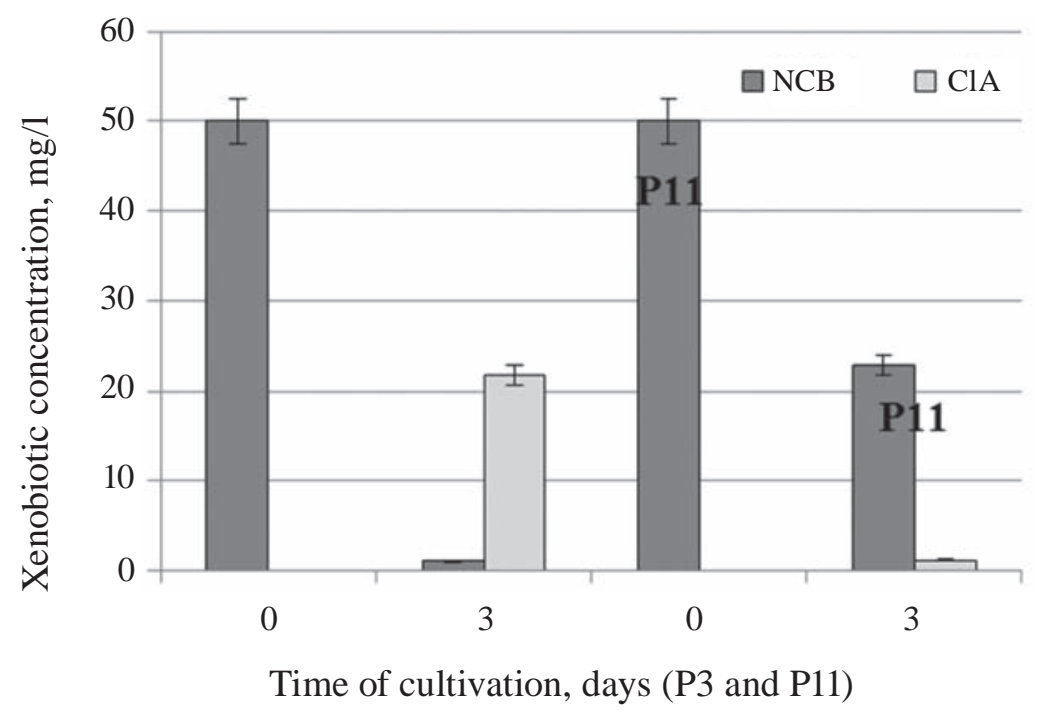

Fig. 1. Consistent NCB transformation by Mushkarova Yama strains. Note: The gray marked NCB is marked by dark grey color, ClA - by white color $(M \pm m, n=3)$ 


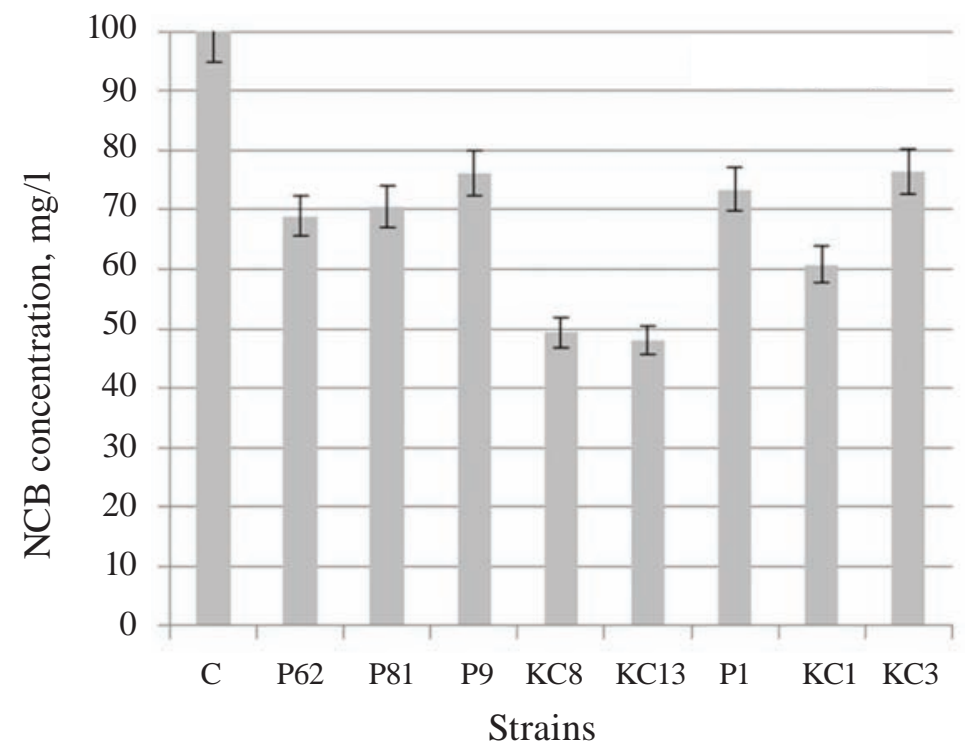

Fig. 2. Reducing of NCB concentration by copio- and oligocarbotrophic cave strains (initial concentration is $100 \mathrm{mg} / \mathrm{l} \mathrm{NCB)}$. Note: strains with the name "P" - Mushkarova Yama, strains "KC" - Kuybyshevskaya cave $(M \pm m, n=3)$

Copio- and oligocarbotrophic strains of both karst caves have shown the ability to interact with NCB (Fig. 2). The average reducing of NCB concentration by studied strains was $30 \%$. The most active strains KC8, KC13 decreased xenobiotic concentration 2 times during three days of cultivation.

Maximum permissible concentrations of NCB were determined for studied strains (Table). Almost all strains were resistant to very high concentrations of xenobiotic - 100-300 mg/l. It should be noted that resistance to NCB did not depend on strains pigmentation.

Taking into account that the concentration of NCB in such wastewater does not exceed $50 \mathrm{mg} / \mathrm{l}$, we could assume high effectiveness of xenobiotic destruction [10, 11].

Biochemical mechanisms of aromatic xenobiotic transformation which was the reason of the bacterial viability in the NCB concentration gradient were shown on the example of toxic persistent organic xenobiotic NCB. Isolated strains could transform NCB, which explained their high resistance to organic xenobiotic. Transformation occured by partial reducing to $\mathrm{ClA}$ and apparently further destruction of the aromatic ring. The most active isolated strains could potentially be used in new environmentaly friendly biotechnology creation for wastewater treatment of organic synthesis enterprises.

\section{Acknoledgements}

The authors express their gratitude to the group of cavers and personally Olga Tkacheva (Ukrainian Speleological Association) for their assistance in caves clays sampling.

\section{БIОХIМІЧНI МЕХАНІЗМИ СТІЙКОСТІ ДО n-НІТРОХЛОРБЕНЗОЛУ МІКРООРГАНІЗМІВ КАРСТОВИХ ПОРОЖНИН}

О. С. Суслова 1 , П. В. Рокитко, К. М. Бондар 2 , О. О. Голубенко O. Б. Taширев $^{1}$

${ }^{1}$ Інститут мікробіології і вірусології ім. Д. К. Заболотного НАН України, Київ;

${ }^{2}$ Київський національний університет імені Тараса Шевченка, Україна; e-mail: olga.suslova11@gmail.com

Встановлено біохімічні механізми стійкості до чужорідного персистентного органічного ксенобіотика $n$-нітрохлорбензолу (НХБ) штамів, ізольованих із глин двох карстових порожнин - Мушкарової Ями (Поділля, Україна) та Куйбишевської (Західний Кавказ, Абхазія). Показано, що хемоорганотрофні мікроорганізми 
Maximum permissible concentrations of NCB for strains isolated from Mushkarova Yama and Kuybyshevskaya caves

\begin{tabular}{|c|c|c|}
\hline Ecosystem, conditions* & Strain & MPC of NCB, mg/l \\
\hline \multirow[t]{6}{*}{ Mushkarova Yama, CC, $850 \mathrm{mg} \mathrm{C/l}$} & PD1 & 200 \\
\hline & $\mathrm{P} 1$ & 300 \\
\hline & P3 & 300 \\
\hline & $\mathrm{P} 4$ & 300 \\
\hline & P41 & 300 \\
\hline & P80 & 200 \\
\hline \multirow[t]{7}{*}{ Mushkarova Yama, OC, $85 \mathrm{mg} \mathrm{C/l}$} & P61 & $<10$ \\
\hline & P62 & 300 \\
\hline & P71 & 100 \\
\hline & P72 & 300 \\
\hline & P81 & 300 \\
\hline & P9 & 300 \\
\hline & P11 & 300 \\
\hline \multirow[t]{4}{*}{ Kuybyshevskaya, CC, $850 \mathrm{mg} \mathrm{C/l}$} & KC1 & 300 \\
\hline & KC2 & 50 \\
\hline & KC3 & 200 \\
\hline & KC4 & 70 \\
\hline \multirow[t]{8}{*}{ Kuybyshevskaya, OC, $85 \mathrm{mg} \mathrm{C/l}$} & KC6 & 300 \\
\hline & KC7 & 100 \\
\hline & KC8 & 300 \\
\hline & KC9 & 100 \\
\hline & KC10 & 100 \\
\hline & KC11 & 100 \\
\hline & KC12 & 100 \\
\hline & KC13 & 300 \\
\hline
\end{tabular}

Note: $* \mathrm{CC}-$ copiocarbotrophic conditions, $\mathrm{OC}$ - oligocarbotrophic conditions

карстових порожнин взаємодіють 3 НХБ, відновлюючи нітрогрупу 3 утворенням $n$-хлораніліну (ХА) та подальшим ймовірним руйнуванням ароматичного кільця. Це пояснює стійкість штамів карстових порожнин до надвисоких концентрацій ксенобіотика. Досліджені штами в перспективі можуть бути використані для очистки стічних вод від нітрохлорароматичних сполук.

К л ю чо в і сл о в а: біохімічний механізм, мікробна деструкція, $n$-нітрохлорбензол, органічні ксенобіотики. 


\section{БИОХИМИЧЕСКИЕ МЕХАНИЗМЫ УСТОЙЧИВОСТИ К $\boldsymbol{n}$-НИТРОХЛОРБЕНЗОЛУ МИКРООРГАНИЗМОВ КАРСТОВЫХ ПОЛОСТЕЙ}

\author{
О. С. Суслова 1 , П. В. Рокитко \\ К. М. Бондарь ${ }^{2}$, А. А. Голубенко \\ А. Б. Таширев ${ }^{1}$
}

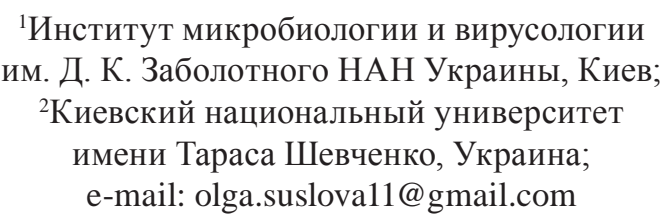

Изучены биохимические механизмы устойчивости к персистентному органическому ксенобиотику $n$-нитрохлорбензолу (НХБ) штаммов, изолированных из глин двух карстовых полостей - Мушкаровой Ямы (Подолье, Украина) и Куйбышевской (Западный Кавказ, Абхазия). Установлено, что хемоорганотрофные микроорганизмы карстовых полостей взаимодействуют с НХБ, восстанавливая нитрогруппу с образованием $n$-хлоранилина (XА) и дальнейшим возможным разрушением ароматического кольца. Это объясняет устойчивость штаммов карстовых полостей к сверхвысоким концентрациям ксенобиотика. Исследуемые штаммы в перспективе могут быть использованы для очистки сточных вод от нитрохлорароматических соединений.

$\begin{array}{lr}\text { К л ю че в ы е } & \text { с лов а: } \\ \text { ский } & \text { механизм, } \\ \text { n-нитрохлорбензол, органические ксенобиотики. }\end{array}$

\section{References}

1. Gvozdyak P. I., Mogilevich N. F., Tashyrev A. B. Transformation of p-nitrohlorobenzene by E. coli. Microbiologiya. 1983;52(1):22-25. (In Russian).

2. Tashyrev A. B., Matveeva N. A., Romanovskaya V. A., Tashyreva A. A., Rokitko P. V. Polyresistance superstability and heavy metals Antarctic microorganisms. Dopovidi Nats. Akad. Nauk Ukrainy. 2007;11:170-175. (In Russian).

3. Tashyrev A. B., Rokitko P. V., Levishko A. S., Romanovskaya V. A., Tashyreva A.A. Resistance to toxic metals of chemoorganotrophic bacteria isolated from the Antarctic cliffs. Mikrobiol. Zhurn. 2012;74(2):3-7. (In Russian).

4. Tashyrev A. B., Romanovskaya V. A., Rokitko P. V., Tashyreva A. A. Multiple resistance to toxic metals of Antarctic cliffs microorganisms (o.Galindez). Ukr. Antarktichny Zhurn. 2011-2012;11-12:212-221. (In Russian).

5. Suslova O., Govorukha V., Brovarskaya O., Matveeva N., Tashyreva H., Tashyrev O. Method for determining organic compound concentration in biological systems by permanganate redox titration. Int. J. Bioautomation. 2014;18(1):45-52.

6. Zhang L., Wang X., Jiao Y., Chen X., Zhou L., Guo K., Ge F., Wu J. Biodegradation of 4-chloronitrobenzene by biochemical cooperation between Sphingomonas sp. strain CNB3 and Burkholderia sp. strain CAN6 isolated from activated sludge. Chemosphere. 2013;91(9):1243-1249.

7. Wu H., Wei C., Wang Y., He Q., Liang S. Degradation of o-chloronitrobenzene as the sole carbon and nitrogen sources by Pseudomonas putida OCNB-1. J. Environ. Sci. 2009;21(1):8995.

8. Arora P. K., Sasikala Ch., Ramana Ch. V. Degradation of chlorinated nitroaromatic compounds. Appl. Microbiol. Biotechnol. 2012;93(6):2265-2277.

9. Tashyrev A. B., Tihnenko S. A. Transformation of $p$-ntrohlorbenzene by obligate anaerobic microorganisms. In the book. "Microbiology of water treatment": Abstracts 2 Union Conference. Kiev, 1982. P. 194. (In Russian).

10. Desai C., Pathak H., Madamwar D. Advances in molecular and "-omics" technologies to gauge microbial communities and bioremediation at xenobiotic/anthropogen contaminated sites. Bioresource Technol. 2010;101(6):1558-1569.

11. Li Haixiang, Yang Xin, Zhong Fohua, Li Junying, Xia Siqing. Experimental study on para-nitrochlorobenzene (p-NCB) removal from groundwater by autohydrogenotrophic microorganism. Chinese J. Environ. Eng. 2011;2:43-48.

Received 23.04.2015 